\title{
Removal of heavy metals from a contaminated soil using phytoremediation
}

\author{
Georgiana Luiza Arnold Tatu, Nicolae Valentin Vladut, Iulian Voicea, Nicoleta Alexandra \\ Vanghele, and Mirabela Augustina Pruteanu*, \\ National Research - Development Institute for Machines and Installations Designed to Agriculture \\ and Food Industry, 6 Ion Ionescu De La Brad Blv., 013813 Bucharest, Sector 1, Romania
}

\begin{abstract}
Environment pollution with heavy metals, can be a cause of the industrialization activities and technological processes, and has become an important issue. Soil contamination due to natural or anthropogenic causes (such as mining, smelting, warfare and military training, electronic industries, fossil fuel consumption, waste disposal, agrochemical use and irrigation) is a major environmental hazard. Various remediation techniques have been highlighted to clean or restore soils contaminated with heavy metals such physical, chemical or biological. Phytoremediation is a relatively new approach to removing contaminants from the environmental. It may be defined as the use of plants to remove, destroy or sequester hazardous substances from environmental. This paper is a review of removal of heavy metals from a contaminated soil using phytoremediation.
\end{abstract}

\section{Introduction}

Brassicaceae is one of the largest angiosperm families, predominant in the temperate region and best cultivated around the Mediterranean. They belong to a group of natural plants conduplicate cotyledons (rare acumbent or existing) and the segment (rare lomentaceous or nucciform) fruit, usually in general, tanks and have flowers with four petals of equal size in the shape of a cross "crucifer" [1-5].

The Brassicaceae family can have a large number of genres and species: ranging from 338 to 380 genres and from 2500 to ca. 3700 species, and includes several genera like Camelina, Crambe, Sinapis, Thlaspi and Brassica. The genus Brassica is the most important one within the tribe Brassiceae, which includes some crops and species of great worldwide economic importance such as Brassica oleracea L., Brassica napus L. and Brassica rapa L. Brassica oleracea is a good example with broccoli (Botrytis group), cauliflower (Botrytis group), cabbage (Capitata group), kale (Acephala group), kohlrabi (Gongylodes group) and brussels sprouts (Gemmifera group) being varieties or convars of the same polymorphic species. Other well-known species within the Brassicaceae are Brassica rapa (turnip, chinese cabbage), Brassica napus (rape, swede/rutabaga), Brassica juncea (indian/brown mustard), Sinapis alba or Brassica hirta (white mustard), Brassica nigra (black mustard),

\footnotetext{
Corresponding author: pruteanu_augustina@yahoo.com
} 
Armoracia rusticana (horse-radish), Raphanus sativus (radish, daikon), Barbarea verna (land cress), Nasturtium officinale (watercress), Eruca vesicaria subsp.sativa (arugula) and Wasabi japonica (wasabi) [1], [6-8].

Cruciferous vegetables are a precious source of bioactive compounds, such as polyphenols and antioxidants, and a rich source of glucosinolates and their hydrolysis products, including indoles and isothiocyanates, which offer more health benefits [3], [6], [9-11]. Although horticultural plants provide a supply of fiber, vitamins and minerals, most research has focused on the content of secondary metabolites, mainly glucosinolate. Recent studies have shown that if food is formed, mainly from Brassicaceae, there is an improvement in human health, can play a role in the prevention and treatment of inflammation, various gastrointestinal and digestive diseases and chronic diseases [12-14].

Heavy metals and metalloids have been a major threat to human health and the environment due to the lack of biodegradability, toxicity, persistence and bioaccumulation in the food chain. They are responsible for causing various disorders in humans, including diseases such as Itai-Itai, Parkinson's, Alzheimer's, Wilson's, Menkens, can, also, affect the nervous and cardiovascular system, some organs (kidneys, liver, heart) [15-19].

Rapid industrialization and urbanization have contributed to the pollution of soil and groundwater with various heavy metals, such as: $\mathrm{Cd}, \mathrm{Pb}, \mathrm{Cu}, \mathrm{Hg}, \mathrm{As}, \mathrm{Se}, \mathrm{Zn}, \mathrm{Ni}[20,21]$. The anthropogenic causes (such as mining, smelting, warfare and military training, electronic industries, fossil fuel consumption, waste disposal, agrochemical use and irrigation) can contaminate the soil, for example: fossil fuels (coal) contain heavy metals such as $\mathrm{Hg}, \mathrm{Pb}, \mathrm{Cd}, \mathrm{Cr}, \mathrm{Cu}, \mathrm{Co}, \mathrm{Zn}$ and $\mathrm{Ni}$ in concentrations of 0.1 to $18 \mathrm{mg} \mathrm{kg}^{-1}$; these heavy metals are released into the environment by vapours, flue gas particles, fly ash and ash from coal combustion [22, 23]. Another possibility to pollute the soil with heavy metals is waste from construction materials and inappropriate soil storage in industrial mines. Field application of phosphorus (P) fertilizers in a critical level and in the longer period, Cubased pesticides, biosolids and animal manure and irrigation of wastewater and poorly treated industrial wastewaters are the main ways for pollutants to enter into soils which can cause environmental issues [20], [24]. Globally there are $>5$ million sites covering 20 million ha of land in which the soils are contaminated by different heavy metal(loid)s [25, 26]. A number of physical, chemical and biological techniques can be used to remediate metal contaminated soils. A promising, relatively new technology for heavy metal contaminated sites is phytoremediation, ecological remediation technologies that use plants as the main source. With this technology, organic and inorganic substances are removed from the contaminated area by using plants. The effects of this method can be observed in low polluted areas in a short time. The negative aspect is that in heavy contaminated areas the plants cannot be useful in a period of short time. Phytoremediation is the use of plants to remove organic and/or inorganic contaminants from biota (phytoextraction), uptake and conversion into non-toxic forms (phytovolatilization), or stabilization of an inorganic into a less soluble form (phytostabilization). Unlike the previously mentioned conventional methods, phytoremediation is inexpensive, effective, can be implemented in situ, and is environmentally friendly. A special advantage of phytoremediation is that soil functioning is maintained and life is soil reactivated [27]. As such, phytoremediation is often referred to botanical bioremediation or green remediation [28, 29]. The success of phytoremediation depends upon the ability of a plant to uptake and translocates heavy metals, a function of the specific phenotype and genotype. Phytoremediation of heavy metal contaminated soil is a developing technology that aims to extract or in-activate metals and it has attracted much attention be-cause it is an environmentally friendly and relatively cheap technique [30,31]. There are two basic strategies under development. The first is the uses of hyper accumulator plants that have the capacity to hyper accumulate heavy metals, and the second is chemical chelate-enhanced phytoextraction [32]. 
Plant species besides hyperaccumulators can also be used, as the heavy metals need not be translocated to the shoots. Terrestrial plants are widely preferred for rhizofiltration as they have fibrous root systems with fast growth. The rhizofiltration technique can be constructed either as floating rafts on ponds or as tank systems. One of the main disadvantages of rhizofiltration involves growing plants in a greenhouse first and then transferring them to the remediation site. Great care must be taken to maintain an optimum $\mathrm{pH}$ in the effluent solution $[33,34]$.

The application of other plants, such as Brassica juncea (Indian mustard), which accumulate target heavy metals to a lesser extent but produce more aboveground biomass so that overall accumulation is comparable to that of hyper accumulators due to production of more biomass [35, 36]. According to Chaney et al. (1997), hyperaccumulation and hypertolerance are more important in phytoremediation than high biomass. Use of hyperaccumulators will yield a metal-rich, low-volume biomass, which is economical and easy to handle in case of both metal recovery and safe disposal. On the other hand use of non-accumulators will yield a metal-poor, large-volume biomass, which will be uneconomical to process for recovery of metals and also costly to safely dispose [37].

This review paper includes an assessment of the phytoremediation of soil contaminated with lead, copper and zinc using just vegetables from brassicaceae family or vegetables with adding chelating agent (EDTA) in the soil and of the accumulation of the metals to the different vegetative parts.

\section{Phytoremediation of soil using vegetables from brassicaceae family (cruciferous)}

Heavy metals can pollute the environment from natural or anthropogenic sources. Lead can reach the environment by urban traffic using leaded fuels, pesticides, herbicides, insecticides, electric batteries, the anthropogenic sources for copper are agriculture, industrial waste, zinc fertilizers, pesticides and for zinc are mining and metallurgic operations, pesticides and fertilizers [33], [38, 39].

Phytoremediation process depends on the capacity of a plant to grab heavy metals, depending on the specific phenotype and genotype. When chelating agents are used, such as ethylenediamine triacetic acid (EDTA), N- (2-hydroxyethyl) -ethylenediaminetriacetic acid acid (HEDTA), citric acid (CA), etc., increases the mobility of the metal, thereby enhancing phytoextraction [39-41]. In general, it was observed that EDTA behaves as a persistent pollutant in the environment, enhancing the mobility and bioavailability of heavy metals.

Brassica juncea (Indian mustard) is one of the most used plants from Brassicaceae family that can remove different heavy metals from contaminated soil [39], [42-45].

\subsection{Lead}

Phytoremediation of a soil contaminated with lead using Brassica juncea (Indian mustard) has good results. Some studies confirm that Brassica juncea can best accumulate this heavy metal in roots, followed by fruit and shoot. The higher concentration of $\mathrm{Pb}$ in root it is due to deep of roots in soil and roots ability for $\mathrm{Pb}$ accumulation. The effect of interaction between soil and plant organs on lead accumulation in Brassica juncea plant show that the highest value was in the interactin between contaminated soil and root part, and the lowest value was in the interaction between uncontaminated soil and shoots [42].

EDTA and Brassica juncea increased the accumulation of lead from the contamination soil. Concentration of $\mathrm{Pb}$ in shoots of Indian mustard was also increased by EDTA addition [43]. Ornamental kale (Brassica oleracea var. Acephala) is usually planted from early 
autumn until late winter. Since most of the plants used for phytoremediation cannot be grown during this time, kale can be a suitable option for phytoremediation and utilized during autumn and winter in urban landscape, especially in metropolitan areas where high levels of lead $(\mathrm{Pb})$ pollutions exist. In general, under salinity stress, kale var.acephala was able to absorb lead [46]. According to Marchiol el all radish showed a relatively low phytoremediation potential of multicontaminated soil [47]. The overall results obtained indicate that there exists a non-linear positive relationship between the lead concentrations in the soil and that accumulated in radish (Raphanus sativus) roots and shoots. It was also observed that by increasing the lead concentration in soil, its accumulation in plant tissues increased. The major lead accumulation occurred in the roots rather than shoots [48]. Eficient $\mathrm{Pb}$ uptake was observed in the roots of contaminated radish compared with the control. Accumulation metal element in the roots was, much higher than in shoot and leaves. Root growth increased by increasing the lead ion concentration. Root length of radish contaminated plant is not affected under the toxicity of all concentration of lead metal, showed susceptibility to elevated levels of lead metal. Lead exposure influenced several biochemical and physiological parameters. Administration of excess amount of lead was followed by an increase of $\mathrm{Pb}$ ions and its associated symptoms of toxicity in leaves [49]. Chinese cabbage can accumulate $\mathrm{Pb}$ in shoots [50]. Hamvumba et all show that Chinese cabbage (Brassica chinensis) has a poor growth pattern as the concentration of lead in the soil increased among treatments. A good characteristic of Chinese cabbage is that this plant is appropriate for phytoremediation and should accumulate metals only in the roots [51].

\subsection{Copper}

Brassica juncea used soil decontamination with copper has a significant difference between $\mathrm{Cu}$ accumulations in fruits and $\mathrm{Cu}$ accumulation in shoots, but there is no significantly difference between the value of $\mathrm{Cu}$ accumulation in fruits and roots. Plant uptake of heavy metals from soil accurs either passively with the mass flow of waer into the roots, or through active transport crosses of the plasma membrane of root epiderma cells. From the interaction between soil and plant parts it can be seen that the highest value was in the interaction between contaminated soil and fruits, whereas the lowest value was in the interaction between control soil and shoots. May this due to $\mathrm{pH}$ of soil and the large biomasses of fruits in Brassica juncea plant [42].

Brassica juncea and EDTA increased the accumulation of $\mathrm{Cu}$. Concentration of $\mathrm{Cu}$ in shoots of Indian mustard was also increased by EDTA addition [43]. A study using Chinese turnip show that copper is accumulated in the plant from a soil contaminated [52].

\subsection{Zinc}

Brassica juncea plant parts has a significantly effects on $\mathrm{Zn}$ accumulation, ithe highest value was in shoots and the lowest value was in roots. This plant is able to accumulate unusually high concentrations of $\mathrm{Zn}$ in their aboveground parts. In the interaction between sol and plant parts it can be notice some significantly difference on $\mathrm{Zn}$ accumulation in plant, the highest accumulation of $\mathrm{Zn}$ was in the interaction between shoots and contaminated soil, where the lowest accumulation of $\mathrm{Zn}$ was in the interaction between roots and control soil [42].

Adding EDTA in a soil with Brassica juncea has no effect for $\mathrm{Zn}$ decontamination soil. Chelate-enhanced phytoextraction might not be an adequate technique for a soil from a paddy field [43]. According to Li et. all Chinese turnips have a strong ability to accumulate zinc [52]. Zinc can be accumulated in shoots in Chinese cabbage [50]. 


\section{Results}

Compared the tolerance of three Brassica species to a multicontaminated soil and, based on a calculated tolerance index, concluded that the tolerance order was B. juncea $>$ B. carinata $>$ B. oleracea [53].

Effect of interaction between soil and Indian mustard shoots on $\mathrm{Pb}, \mathrm{Cu}$ and $\mathrm{Zn}$ accumulation are presented in table 1 and data on metals accumulation in different vegetative parts, metal translocation, polyphenols and total chlorophyll, by three plants of Brassica juncea in table 2.

Table 1. $\mathrm{Pb}, \mathrm{Cu}$ and $\mathrm{Zn}$ accumulation in shoots Indian mustard planted in contaminated and uncontaminated soil (control)

\begin{tabular}{|c|c|c|c|c|c|c|c|c|}
\hline \multirow[t]{2}{*}{$\begin{array}{l}\text { Method } \\
\text { applied }\end{array}$} & \multirow[t]{2}{*}{ Soil type } & \multicolumn{3}{|c|}{$\begin{array}{c}\text { Concentration metals in } \\
\text { soil, ppm }\end{array}$} & \multicolumn{3}{|c|}{$\begin{array}{l}\text { Concentration metals in } \\
\text { shoots Indian mustard, } \\
\text { ppm }\end{array}$} & \multirow[t]{2}{*}{ References } \\
\hline & & $\mathrm{Cu}$ & $\mathrm{Zn}$ & $\mathrm{Pb}$ & $\mathrm{Cu}$ & $\mathrm{Zn}$ & $\mathrm{Pb}$ & \\
\hline \multirow{3}{*}{$\begin{array}{l}\text { EDTA } \\
\text { and } \\
\text { Indian } \\
\text { mustard }\end{array}$} & control & 15.30 & 460 & 5.60 & 0.12 & 3.68 & 0.04 & \multirow[b]{2}{*}[43]{$^{*}$} \\
\hline & $\begin{array}{c}\text { contaminated } \\
\text { soil }\end{array}$ & 39.80 & 471 & 15.80 & 0.29 & 3.41 & 0.12 & \\
\hline & control & 18.60 & 32.20 & 8.65 & 4.20 & 8.75 & 3.14 & {$[54]^{* *}$} \\
\hline \multirow{2}{*}{$\begin{array}{l}\text { Indian } \\
\text { mustard }\end{array}$} & control & 32.30 & 106.90 & 11.10 & 9.30 & 28.40 & 1.50 & \multirow[b]{2}{*}[50]{$^{* * *}$} \\
\hline & $\begin{array}{c}\text { contaminated } \\
\text { soil }\end{array}$ & 114.20 & 1132.50 & 271.30 & 24.70 & 250.60 & 18.40 & \\
\hline
\end{tabular}

*Metals were determined using a Thermo Jarrell Ash ICP-AES [43]; **Metals were determinated by atomic absorption spectrophotometer (AOAC 1990). [54]; ${ }^{* * *}$ Concentrations of metals were determined with atomic absorption spectroscopy (AAS) following $\mathrm{HNO}_{3}-\mathrm{HClO}_{4}$ digestion [50].

Table 2. Accumulation of metals in Brassica Juncea under pot assay [55]

\begin{tabular}{|c|c|c|c|c|c|c|c|}
\hline \multirow{2}{*}{ Metals } & $\begin{array}{c}\text { Concen } \\
\text { tration } \\
{[\mathrm{mg} / \mathrm{kg}]}\end{array}$ & \multicolumn{2}{|c|}{$\begin{array}{c}\text { Metal uptake }[\mu \mathrm{g} / \mathrm{g}] \text { in } \\
\text { plant parts }\end{array}$} & $\begin{array}{c}\text { Metal } \\
\text { translocation } \\
\text { factor }\end{array}$ & $\begin{array}{c}\text { Polyphenols }^{* *} \\
{[\mu \mathrm{g} / \mathrm{ml}]}\end{array}$ & $\begin{array}{l}\text { Total chlorophyll }^{* * *} \\
{[\mathrm{mg} \% \text { fresh weight }]}\end{array}$ \\
\hline \multirow{2}{*}{$\mathrm{Cu}$} & 10 & 15.27 & 37.18 & 43.12 & 0.61 & 0.32 & 38.70 \\
\cline { 2 - 8 } & 25 & 29.28 & 33.15 & 47.12 & 0.66 & 0.56 & 40.10 \\
\hline \multirow{2}{*}{$\mathrm{Pb}$} & 10 & 32.11 & 41.13 & 58.10 & 0.63 & 0.76 & 56.42 \\
\cline { 2 - 8 } & 25 & 38.11 & 80.31 & 101.13 & 0.59 & 0.35 & 58.11 \\
\hline \multirow{2}{*}{$\mathrm{Zn}$} & 10 & 19.88 & 16.68 & 26.57 & 0.69 & 0.68 & 13.26 \\
\cline { 2 - 7 } & 25 & 36.12 & 21.44 & 57.49 & 0.50 & 0.25 & 18.00 \\
\hline
\end{tabular}

*Metal analysis of all digested samples was performed by atomic absorption spectrometry [55]; **The concentration of total soluble phenolics in plants was estimated using a standard curve [55]; ***The chlorophyll contents were estimated by extracting fresh plant following the methods of Arnon [55].

Lead uptake was highest in leaves and stem where as zinc accumulation was highest in roots. Copper were least preferred metals for accumulation by the plants.

\section{Conclusion}

Increased urbanization and industrialization is responsible for the contaminatin of soil with metals. The ability of brassicas to bioaccumulate heavy metals can be used to reduce the level of contaminants in the soil (phytoremediation), and thus to clean up and prepare soils for cultivation. Brassica juncea plant was able to grow in heavy metals contaminated soil and also able to accumulate extraordinarily high concentrations of some metals in their roots, stems and/or leaves, to far exceeding levels than present in the soil.

EDTA-enhanced phytoextraction would not remove adequate quanities of heavy metals from soil. EDTA have capacity to reduce the cost and time required for remediation of heavy-metal-polluted soil by increasing the bioaccumulation index of metal in plants.

The result of EDTA in the environment is an enhanced mobilization of heavy metals. 
This paper was financed by support of Executive Agency for Higher Education, Research, Development and Innovation Funding, Exploratory Research Programme, PN-III-P4-ID-PCE-20160860, contr. 174/ 08.08.2017, Research on the development of some mathematical models to evaluate the impact of soil contamination on fruits and vegetables - CONTAMOD and a grant of the Romanian Research and Innovation Ministry, through Programme 1 - Development of the national research-development system, subprogramme 1.2 - Institutional performance - Projects for financing excellence in RDI, contract no. 16PFE.

\section{References}

1. M. M. Marzouk, A.-S. M. Al-Nowaihi, S. A. Kawashty, N. A.M. Saleh, Biochem. Syst. Ecol. 38, 680 (2010)

2. M.B. Crespo, M.D. Lledo, M.F. Fay, M.W. Chase, Ann. Bot.-London 86, 53 (2000)

3. J.V. Higdon, B. Delage, D.E. Williams, R.H. Dashwood, Pharmacol. Res. 55, 224 (2007)

4. I.A. Al-Shehbaz, M.A. Beilstein, E.A. Kellogg, Plant Syst. Evol. 259, 89 (2006)

5. A.R. Kristal, J.W. Lampe, Nutr. Cancer 42, 1 (2002)

6. M. Björkman, I. Klingen, A.N.E. Birch, A.M. Bones, T.J.A. Bruce, T. J. Johansen, R. Meadow, J. Mølmann, R. Seljåsen, L.E. Smart, D. Stewart, Phytochemistry 72538 (2011)

7. M.E. Cartea, M. Francisco, P. Soengas, P. Velasco, Molecules 16, 251 (2011)

8. A. Naska, D. Fouskakis, E. Oikonomou, M.D.V. Almeida, M.A. Berg, K. Gedrich, O. Moreiras, M. Nelson, K. Trygg, A. Turrini, A.M. Remaut, J.L. Volatier, Eur. J. Clin. Nutr. 60, 181 (2005)

9. M. Jahangir, I.B. Abdel-Farida, H.K. Kima, Y.H. Choi, R. Verpoortea, Environ. Exp. Bot. 67, 23 (2009)

10. S. Manchalia, K.N. C. Murthy, B.S. Patil, J. Funct. Foods 4, 94 (2012)

11. A. Mollicaa, A. Stefanuccia, G. Zenginb, M. Locatellia, G. Macedonioa, G. Orlandoa, C. Ferrantea, L. Menghinia, L. Recinellaa, S. Leonea, A. Chiavarolia, L. Leporinia, C. Di Nisioa, L. Brunettia, E. Tayrabc, I. Alid, T. H. Musae, H. H. Musaf, A. A. Ahmedg, Biomed. Pharmacother 107, 129 (2018)

12. D. Šamec, B. Salopek-Sondi, Chapter 3.11, Plant and Algae Extracts, 195 (2019)

13. A. Mazumder, A. Dwivedi, J. Plesis, Molecules 21, 416 (2016)

14. N. Fujioka, B.W. Ransom, S.G. Carmella, P. Upadhyaya, B.R. Lindgren, A. Roper-Batker, D.K. Hatsukami, V.A. Fritz, C. Rohwer, S.S. Hecht, Cancer. Prev. Res. 9, 788 (2016)

15. K.T. Aspli, T.P. Flaten, P.M. Roos, T. Holmoye, J.H. Skogholt, J. Aaseth, J. Trace Elem. Med. Bio. 31, 183 (2015)

16. G.J. Brewer, Inorg. Chim. Acta. 393, 135 (2012)

17. D. Dias, J. Bessa, S. Guimara, M.E. Soares, M. De Laurdes Bastos, H.M. Teixeira, Forensic. Sci. Int. 259, 20 (2016)

18. H.A. Yassa, Environ. Toxicol. Phar. 38, 1016 (2014)

19. H.M. Korashy, I.M. Attafi, K.S. Famulski, S.A. Bakheet, M.M. Hafez, A.M.S. Alsaad, A. Rahman, M. Al-Ghadeer, Environ. Pollut. 221, 64 (2017)

20. S. Khalid, M. Shahid, N. K. Niazi, B. Murtaza, I. Bibi, C. Dumat, J. Geochem. Explor. 182, 247 (2017)

21. T.V. Minnikova, T.V. Denisova, S.S. Mandzhieva, S.I. Kolesnikov, T.M Minkina, V.A. Chaplygin, M.V. Burachevskaya, S.N. Sushkova, T.V. Bauer, J. Geochem. Explor. 174, 70 (2017)

22. L. Liu, W. Li, W. Song, M. Guo, Sci. Total Environ. 633, 206 (2018)

23. H. Nalbandian, IEA Clean Coal Center, London, UK (2012)

24. N. Bolan, A. Kunhikrishnan, R. Thangarajan, J. Kumpiene, J. Park, T. Makino, M.B. Kirkham, K. Scheckel, J. Hazard. Mater. 266, 141 (2014)

25. R.A. Wuana, F.E. Okieimen, J.A. Imborvungu, Int. J. Environ. Sci. Tech. 7, 485 (2011) 
26. J. He, J.P. Chen, Bioresour. Technol. 160, 67 (2014)

27. S. Trapp, U. Karlson, J. Soils Sediments 1, 1 (2001)

28. R.L. Chaney, M. Malik, Y.M. Lim, S.L. Brown, E.P. Brewer, J.S. Angle, A.J.M. Baker, Curr. Opin. Biotechnol. 8, 279 (1997)

29. J. Zavoda, T. Cutright, J. Szpak, E. Fallon, J. Environ. Eng. 127, 502 (2001)

30. S.P. McGrath, CAB International, Wallingford, UK 261 (1998)

31. S.P. McGrath, F.J. Zhao, E. Lombi, Adv. Agron. 75, 1 (2002)

32. D.E. Salt, R.D. Smith, I. Raskin, Annu. Rev. Plantphysiol. Plant Mol. Biol. 49, 643 (1998)

33. N. Sarwar, M. Imran, M.R. Shaheen, W. Ishaque, M.A. Kamran, A. Matloob, A. Rehim, S. Hussain, Chemosphere 171, 710 (2017)

34. A. Bani, D. Pavlova, G. Echevarria, A. Mullaj, R.D. Reeves, J.L. Moel, S. Sulce, Bot. Serb 34, 3 (2010)

35. B.H. Robinson, M. Leblanc, D. Petit, R.R. Brooks, J.H. Kirkman, P.E.H. Gregg, Plant. Soil 203, 47 (1998)

36. P. Tlustoš, J. Száková, J. Hrubý, I. Hartman, J. Najmanová, J. Nedĕlník, D. Pavlíková, M. Batysta, Plant Soil Environ. 52, 413 (2006)

37. R.L. Chaney, M. Malik, Y.M. Li, S.L. Brown, E.P. Brewer, J.S. Angle, A.J.M. Baker, , Curr. Opin. Biotechnol. 8, 279 (1997)

38. H. Ali, E. Khan, M.A. Sajad, Chemosphere 91, 869 (2013)

39. S.S. Rathore, K. Shekhawat, A. Dass, B.K. Kandpal, V.K. Singh, Proc. Natl. Acad. Sci. India, Sect. B Biol. Sci. 89, 419 (2019)

40. C. Turgut, M.K. Pepe, T.J. Cutright, Environ. Pollut. 131, 147 (2004)

41. G. Kaur Leela, K. Adgil, S. Sharma, EQA Environ. Qual. 17, 13 (2015)

42. A.H. Tahish, J. Plant Production 4, 1417 (2013)

43. L.H. Wu, Y.M. Luo, X.R. Xing, P. Christie, Agr. Ecosyst. Environ. 102, 307 (2004)

44. M.K. Ansari, A. Ahmad, S. Umar, M.H. Zia, M. Iqbal, G. Owens, Int. J. Phytoremediat. 17, 135 (2015)

45. S. Singh, S. Sinha, Ecotoxicol. Environ. Saf. 62, 118 (2005)

46. M. Haghighi, M. Kafi, M. Pessarakli, A. Sheibanirad, M. R. Sharifinia, J. Plant. Nutr. 39, 1460 (2013)

47. L. Marchiol, S. Assolari, P. Sacco, G. Zerbi, Environ. Pollut. 132, 21 (2004)

48. So. Asadi Kapourchal, Sa. Asadi Kapourchal, E. Pazira, M. Homaee, Plant Soil Environ. 55, 202 (2009)

49. N. A. Hamadouche, H. Aoumeur, S. Djediai, M. Slimani, A. Aoues, Acta. Biol. Szegediensis 56, 43 (2012)

50. H.M. Chen, C.R. Zheng, C. Tu, Z.G. Shen, Chemosphere 41, 229 (2000)

51. R. Hamvumba, M. Mataa, A. M. Mweetwa, Environment and Pollution 3, 65 (2014)

52. B. Li, D. Chen, Y. Yang, X. Li, Plant Diversity (2019) doi.org/10.1016/j.pld.2019.06.006

53. C. Gisbert; R. Clemente; J. Navarro-Avino; C. Baixauli; A. Giner; R. Serrano; D.J. Walker; M.P. Bernal, Environ. Exp. Bot., 56, 19-27, (2006).

54. M. Turan, A. Esringü, Plant Soil Environ. , 53, 1 (2007).

55. M.N. Jagtap, M. V. Kulkarni, P. R. Puranik, Trends in Biotechnology, 2, 2, (2013) 